\title{
Mineral Fertilization with UAN on Natural Grassland Festuca rubra L. with Agrostis capillaries $L$.
}

\author{
Ioan ROTAR, Mirela CIREBEA*, Roxana VIDICAN, Florin PĂCURAR, Anamaria MALINAȘ, Ovidiu RANTA \\ Faculty of Agriculture. University of Agricultural Sciences and Veterinary Medicine Cluj-Napoca, \\ Manăștur Street, 3-5, 400372, Romania. \\ *corresponding author: cirebea_mirela@yahoo.com
}

Bulletin UASVM series Agriculture 73(2)/2016

Print ISSN 1843-5246; Electronic ISSN 1843-5386

DOI 10.15835/buasvmcn-agr: 12449

\begin{abstract}
An important part of efficient livestock production is ensuring the sufficient grass for hay and pasture. However, low soil nutrient levels often limit forage production. With good fertilizer management and soil fertility, the productivity of many hay and pasture fields can be greatly improved. Through good fertilizer management, the productivity of many hay and pasture fields can be significantly improved by Ross H. McKenzie (2005). The aim of this paper was the effect of fertilization with liquid fertilizer (UAN) the harvest of dry and floristic composition changing on natural grassland. The experiment whose results we present was placed in 2014 in the place in Baisoara Mountain village, Cluj County. Experience has been placed on the Festuca rubra and Agrostis capillaries - of grassland type. The natural grassland of Festuca rubra with Agrostis capillaries responded very well to mineral fertilizers with liquid fertilizer UAN. The floristic composition of natural grassland fertilized with liquid fertilizers based on nitrogen, it can be seen an increase the Gramineae families and an evidence downward trend from Fabaceae families.
\end{abstract}

Keywords: fertilization, liquid fertilizer, grassland.

\section{INTRODUCTION}

Most pastures are artificial products of people and animals. Realizing an optimum balance pasture and livestock ensures the maintenance and improving permanent vegetation cover. Only by controlling the mutual interaction between the two factors - plant and animal - we can obtain positive economic results (Rotar and Carlier, 2010). The grasslands second order in the village Baisoara exploited by mowing, grazing or mixed. The grasslands in the Apuseni Mountains have a high diversity (Michler et al., 2005) which is strongly influenced by management applied (Stoie, 2011). Increasing trophicity of grasslands by using liquid fertilizers, shows a new system of mineral fertilizer natural grasslands anticipated effects refers to improving the quality, productivity, and floristic composition.

The aim of this paper was the effect of fertilization with liquid fertilizer (UAN) on the harvest of dry and floristic composition changing on natural grassland.

\section{MATERIALS AND METHODS}

The experiment whose results we present was placed in 2014 in the place in Baisoara Mountain village, Cluj county, at the altitude of $1240 \mathrm{~m}$. The experience was placed after experimental technique method. The surface of experimental plots is $20 \mathrm{~m}^{2}$.The experience includes four variants in three repetitions, which are: first variant (V1) control variant, (unfertilized); the second variant (V2) - fertilizer with $50 \mathrm{~kg}$ UAN/ha-1; third variant V 3 - fertilizer with $75 \mathrm{~kg}$ UAN/ha-1 (V4) fertilizer $100 \mathrm{~kg}$ UAN/ha-1.

Experience has been placed on grassland Festuca rubra - Agrostis capillaries type of that is specific of nemoral floor, beech forest the sublevel 
and mixed beech resinous (Țucra et al., 1987) determined after Braun-Blanquet (1932).

Natural grasslands of Festuca rubra with Agrostis capillaris responded particularly well to mineral fertilization with liquid fertilizer UAN which is a mixture of ammonium nitrate and urea (ammonium nitrate, urea). Chemical formula: $\mathrm{NH}^{-}$ ${ }_{4} \mathrm{NO}_{3} \mathrm{NH}_{2}-\mathrm{CO}-\mathrm{NH}_{2}$, as shows the Tab. 1 .

The reaction to the mineral fertilization with liquid fertilizer UAN is particularly strong, registering increases very distinct significant, all variants of experimental compared to control. The variants fertilized with high amounts of fertilizer (V3 and V4), yields are between $19.17-21.83 \mathrm{t} /$ ha green mass.

The floristic studies were conducted before mowing, vegetation scale interpretation given by Braun-Blanquet (1932), when Poaceae family were in the flowering stage (Tab. 5). The typological grasslands were done after T,ucra et al. 1987.

Comparative analysis using the Duncan test of green mass production in 2015 show the differences between the production variants and a tendency to increase production with increasing doses of fertilizer (Tab. 2 and Tab. 3). Thus, V3 reported to V1 it is an $8.67 \mathrm{t} /$ ha green mass difference of harvest and V4 at $11.33 \mathrm{t} /$ ha green mass reported to V1.

The dry matter production for natural grasslands of Festuca rubra with Agrostis capillaries registers values between $2.33 \mathrm{t} /$ ha DM at the control variant and $4.85 \mathrm{t} /$ ha DM in variant most strongly fertilized, with an increase up to $2.52 \mathrm{t} /$ ha DM. Increases are distinct significant and very distinct significant insured statistically, as shown in Table 4.

Tab. 1. Influence of fertilization on green mass yield in 2015 (t/ha)

\begin{tabular}{ccccc}
\hline Dosing of fertilization & Yield (t/ha) & Percent $\%$ & Differences t/ha & Significance \\
\hline V1- 0 kg UAN/ha-1 & 10.50 & 100.0 & 0,00 & Mt. \\
\hline V2- 50 kg UAN/ha-1 & 14.83 & 141.3 & 4.33 & $* * *$ \\
\hline V3- 75 kg UAN/ha-1 & 19.17 & 182.5 & 8.67 & $* * *$ \\
\hline V4- 100 kg UAN/ha-1 & 21.83 & 207.9 & 11.33 & $* * *$ \\
\hline DL (p 5\%) & & & 1.74 & \\
DL (p 1\%) & & & 2.51 & \\
DL (p 0.1\%) & & &
\end{tabular}

Tab. 2. The yield differences among variants and their significance (2015)

\begin{tabular}{ccccc}
\hline & & \multicolumn{3}{c}{ Variants in order of increasing crop } \\
\cline { 3 - 4 } Dosing of fertilization & $\begin{array}{c}\text { Yield }(\mathrm{t} / \\
\text { ha) }\end{array}$ & & \multicolumn{3}{c}{\begin{tabular}{c} 
Green mass \\
\cline { 3 - 4 }
\end{tabular}} & & 14.83 & 19.17 & 21.83 \\
\cline { 3 - 5 } & 10.50 & 4.33 & 8.67 & 11.33 \\
\hline V1- 0 kg UAN/ha-1 & 14.83 & & 4.33 & 7.00 \\
\hline V2- 50 kg UAN/ha-1 & 19.17 & & & 2.67 \\
\hline V3- 75 kg UAN/ha-1 & 21.83 & & \\
\hline V4- 100 kg UAN/ha-1 & & &
\end{tabular}


Tab. 3. The DS 5\% values of significance difference for the various limits of the comparison between variants

\begin{tabular}{cccc}
\hline \multicolumn{4}{c}{ Average error SX $=0.55(\mathrm{t} / \mathrm{ha})$} \\
\hline The distance in classification & 2 & 3 & 4 \\
\hline Values q & 3.20 & 3.34 & 3.42 \\
\hline Theoretical DS values & 1.75 & 1.82 & 1.87 \\
\hline
\end{tabular}

Tab. 4. Influence of fertilization on dry matter yield in 2015 (t/ha)

\begin{tabular}{ccccc}
\hline Dosing of fertilization & Yield (t/ha) & Percent $\%$ & Differences t/ha & Significance \\
\hline V1- 0 kg UAN/ha-1 & 2.33 & 100.0 & 0.00 & Mt. \\
\hline V2- 50 kg UAN/ha-1 & 3.30 & 141.4 & 0.96 & $* * *$ \\
\hline V3- 75 N kg UAN/ha-1 & 4.26 & 182.5 & 1.93 & $* * *$ \\
\hline V4- 100 N kg UAN/ha-1 & 4.85 & 208.0 & 2.52 & $* * *$ \\
\hline DL (5\%) & & & 0.39 & \\
DL (1\%) & & & 0.56 & \\
DL (0,1\%) & & & 0.83 &
\end{tabular}

Tab. 5. The yield differences among variants and their significance (2015)

\begin{tabular}{|c|c|c|c|c|}
\hline \multirow{4}{*}{ Dosing of fertilization } & \multirow{4}{*}{ Yield (t/ha) } & \multicolumn{3}{|c|}{ Variants in order of increasing crop } \\
\hline & & 2 & 3 & 4 \\
\hline & & \multicolumn{3}{|c|}{ Dry matter DM t/ha } \\
\hline & & 3.30 & 4.26 & 4.85 \\
\hline V1- $0 \mathrm{~kg} / \mathrm{ha}$ & 2.33 & 0.96 & 1.93 & 2.52 \\
\hline V2- $50 \mathrm{~N}$ & 3.30 & & 0.96 & 1.56 \\
\hline V3- $75 \mathrm{~N}$ & 4.26 & & & 0.59 \\
\hline V4- $100 \mathrm{~N}$ & 4.85 & & & \\
\hline
\end{tabular}

Tab. 6. The values of significance difference for the various limits of the comparison between variants

\begin{tabular}{cccc}
\hline \multicolumn{4}{c}{ Average error SX $=0.12(\mathrm{t} / \mathrm{ha})$} \\
\hline The distance in classification & 2 & 3 & 4 \\
\hline Values q & 3.20 & 3.34 & 3.42 \\
\hline Theoretical DS values & 0.39 & 0.41 & 0.42 \\
\hline
\end{tabular}




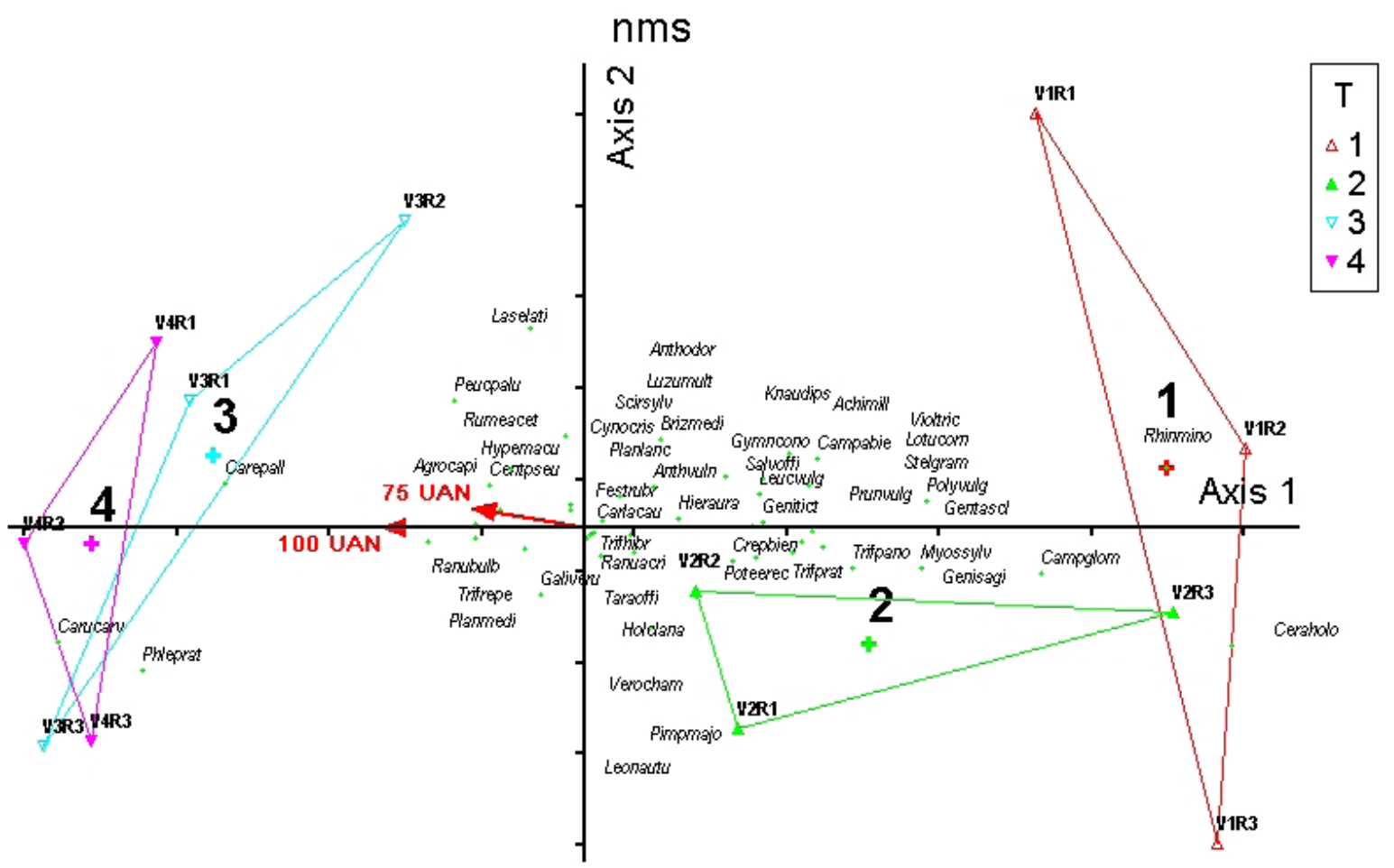

Fig. 1. Ordering floristic composition in 2015, with Pc-ord variant 6 , according to the liquid fertilizer treatments: V1- control variant, (unfertilized); V2 - fertilizer with $50 \mathrm{~kg}$ UAN/ha-1; V 3 - fertilizer with $75 \mathrm{~kg}$ UAN/ha-1; V4 - fertilizer $100 \mathrm{~kg}$ UAN/ha-1

Tab. 7. Pairwise Comparisons

\begin{tabular}{llllc}
\hline \multicolumn{1}{c}{ Compared variants } & T & A & P & Specification \\
\hline 1 vs. 2 & 0.0193 & -0.001 & 0.481 & - \\
\hline 1 vs. 3 & -2.622 & 0.238 & 0.023 & $*$ \\
\hline 1 vs.4 & -2.791 & 0.318 & 0.022 & $*$ \\
\hline 2 vs.3 & -2.434 & 0.153 & 0.026 & $*$ \\
\hline 2 vs.4 & -2.787 & 0.249 & 0.022 & - \\
\hline 3 vs.4 & 0.631 & -0.044 & 0.695 & $*$ \\
\hline
\end{tabular}

Comparative analysis using the Duncan test for dry matter production in 2015 show significant differences (Tab. 5 and Tab. 6) of production between different treatments and a good reaction to the meadow with increasing doses of fertilizer.

The ordering of the floristic composition after fertilization with mineral fertilizer based on nitrogen (UAN), is presented in Fig. 1.
Are significant differences is recorded the comparison between phytocoenosis, such as version control (unfertilized) with the variants V3(fertilizer with $75 \mathrm{~kg}$ UAN/ha-1), V4 (fertilizer with 100 $\mathrm{kg}$ UAN/ha-1) $(\mathrm{p}<0.05)$. In the case comparison of variants V2 (fertilizer with $50 \mathrm{~kg}$ UAN/ha-1) with V3 (fertilizer with $75 \mathrm{~kg}$ UAN/ha-1) and V4 (fertilizer with $100 \mathrm{~kg}$ UAN/ha-1) is also found statistically significant differences $(p<0.05)$. When 


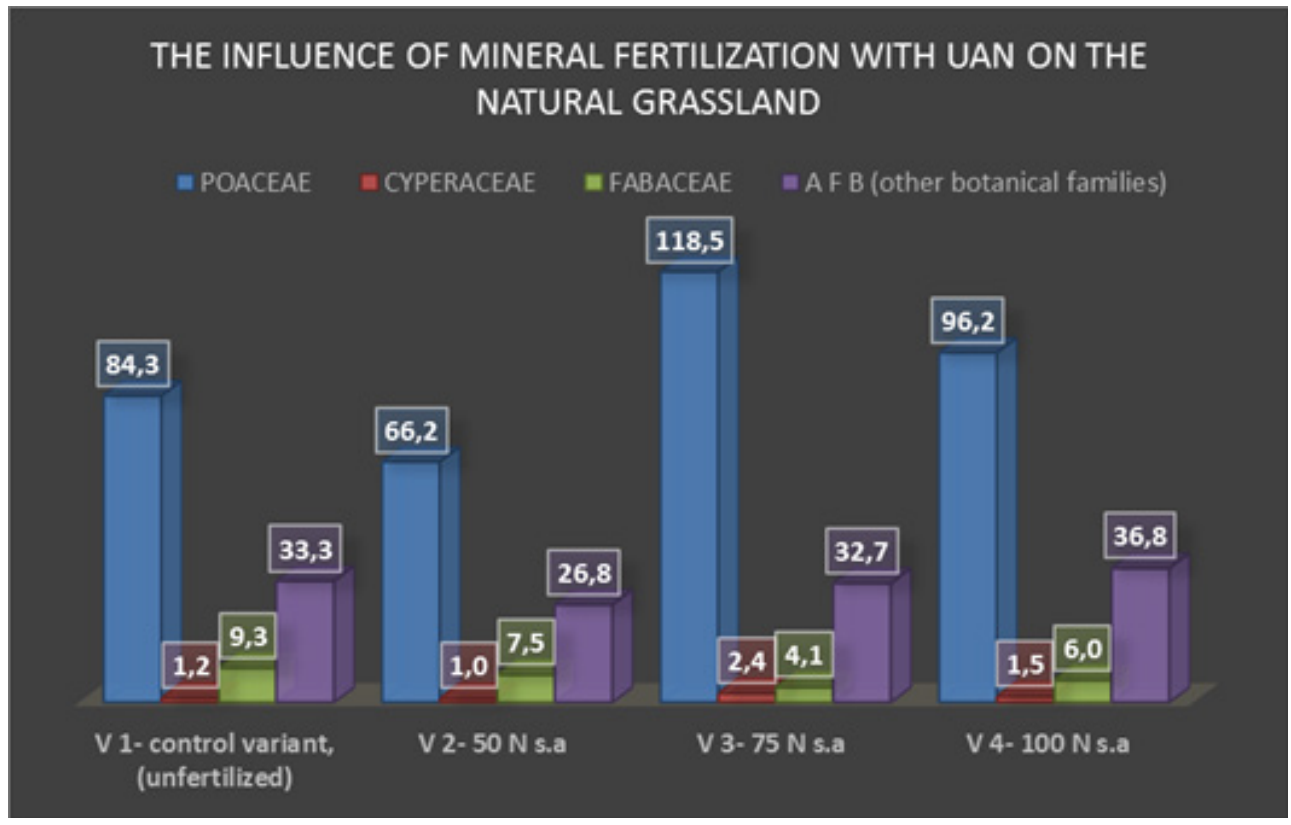

Fig. 2. The influence of mineral fertilization with UAN on natural grassland

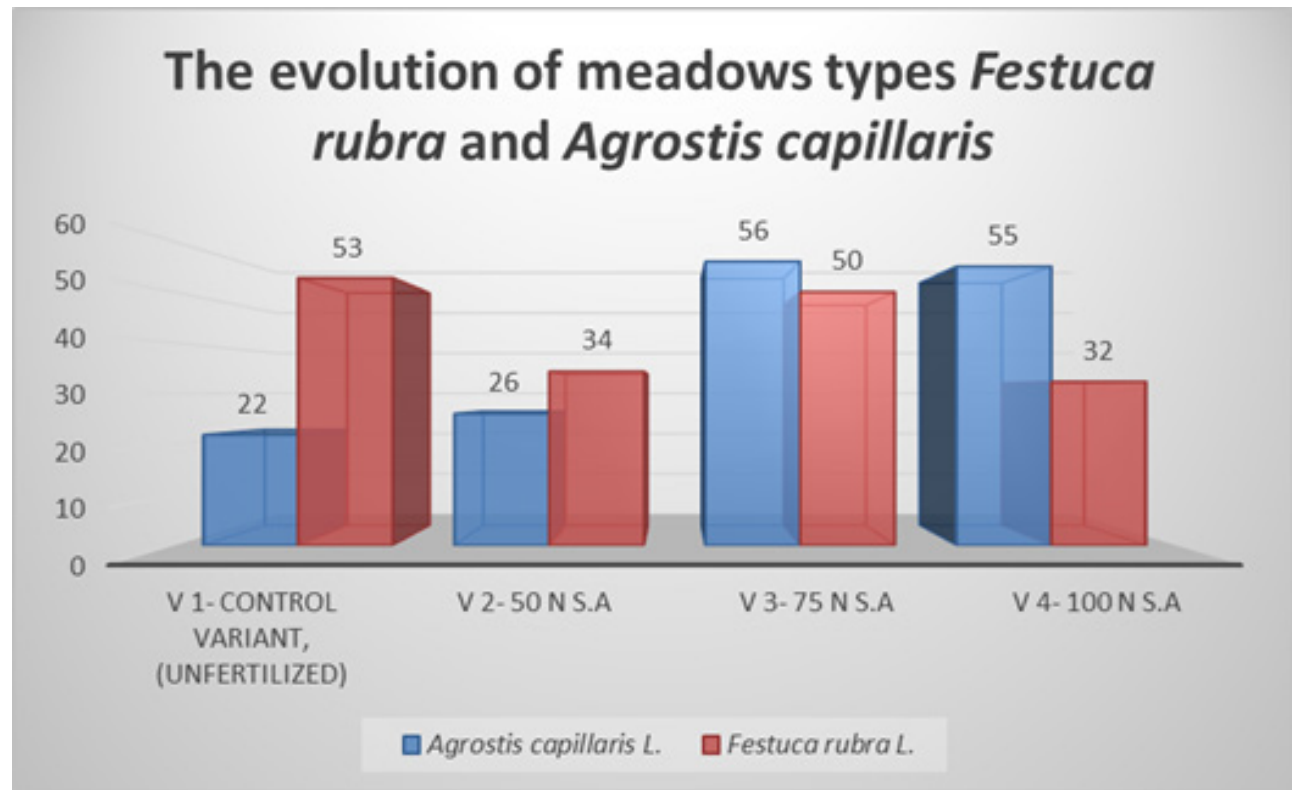

Fig. 3. The evolution of grassland types of Festuca rubra with Agrostis capillaris

compared to the control variant (unfertilized) with the variant V2 (fertilizer with $50 \mathrm{~kg}$ UAN/ha-1) and V3 (fertilizer with $75 \mathrm{~kg}$ UAN/ha-1) with the variant V4 (fertilizer with $100 \mathrm{~kg} \mathrm{UAN} / \mathrm{ha}-1$ ) is not statistically significant differences (p 0.05).

Regarding the floristic composition of natural grassland fertilized with liquid mineral fertilizers based on nitrogen, after the second year can be seen an increase in the share Poaceae family from $84.3 \%$ to $118.5 \%$ at the variant fertilized with 75 $\mathrm{kg}$ UAN/ha- 1 and evident tendency of the Fabaceae family from $9.3 \%$ to $4.1 \%$ unfertilized variant to variant fertilized with $75 \mathrm{~kg}$ UAN/ha-1; plants from other botanical families are decreasing.

The results show that after the second year of the fertilizer with UAN of the grassland type Festu- 
ca rubra with Agrostis capillaries, the application of 75 UAN/ha-1 and 100 UAN/ha-1 to, change the type of grassland and becomes Agrostis capillaries with species co-dominant Festuca rubra. Agrostis capillaries recorded values up to $56 \%$ from unfertilized variant with a value of $22 \%$.

\section{CONCLUSION}

Our research has pioneer character, so we do not have more information on the metabolizing liquid fertilizers from grasslands.

The application of $100 \mathrm{UAN} / \mathrm{ha}-1$ of liquid fertilizer based on nitrogen leads to a difference in harvest of $11.33 \mathrm{t} /$ ha green mass. Evidently, the same trend is kept in dry matter production where the difference in harvest compared to the unfertilized variant is $2.52 \mathrm{t} / \mathrm{ha}$. After a relatively short period of experiment (2 years), we can recommend the use of liquid fertilizers based on nitrogen because it is effective in natural grasslands in the mountain area, we can recommend doses between 50 and 100 UAN/ha-1;

\section{REFERENCES}

1. Braun - Blanquet J (1932). Plant Sociology, the study of plant communities, Ed. Mc-Graw - Hill Book Company, Inc. New - York and London, 31-33.

2. Cirebea M, Rotar I, Păcurar F, Vidican R, Pleşa A, Mălinaș A (2015). Influence of mineral fertilization with Uan on a natural meadow Festuca Rubra with Agrostis Capillaries, Romanian Journal of Grasslands And Forage Crops, 11:2228.

3. McKenzie RH (2005). Fertilizing Grass for Hay and Pasture,. Research Scientist - Agronomy Alberta Agriculture, Food and Rural Development Lethbridge, Alberta.

4. Michler B (2005). The project "The productivity and biodiversity of natural meadows with Arnica montana L. from Apuseni Mountains".

5. Rotar I, Carlier L (2010). Cultura Pajiştilor, Editura Risoprint, Cluj-Napoca.

6. Stoie A (2011). Cercetări asupra ecosistemelor de pajiști cu Arnica montana L în bazinul superior al Arieșului. Teză de doctorat -USAMV Cluj- Napoca.

7. Țucra I., Kovacs AJ, Roşu C, Ciubotariu C, Chifu T, Neacşu M, Bărbulescu C, Cardaşol V, Popovici D, Simtea N, Motcă G, Dragu I, Spirescu M (1987). Principalele tipuri de pajişti din R. S. România, Ed. Poligrafică "Bucureștii Noi". 